\title{
Does latitude drive the phenotypic plasticity of morphological traits in non-native pumpkinseed populations from Europe?
}

\author{
Eva Záhorská ${ }^{1, *}$, Mária Balážová ${ }^{2}$, Yakuta Bhagat ${ }^{3}$ and Gordon H. Copp ${ }^{4,5,6}$ \\ ${ }^{1}$ Department of Ecology, Faculty of Natural Sciences, Comenius University, Bratislava, Slovakia \\ ${ }^{2}$ Department of Biology and Ecology, Pedagogical Faculty, Catholic University, Ružomberok, Slovakia \\ ${ }^{3}$ EnviroScience, Inc., 5070 Stow Road, Stow, Ohio 44224, USA \\ ${ }^{4}$ Centre for Environment, Fisheries and Aquaculture Science, Pakefield Road, Lowestoft, Suffolk NR33 0HT, UK \\ ${ }^{5}$ School of Conservation Sciences, Bournemouth University, Poole, Dorset, UK \\ ${ }^{6}$ Environmental and Life Sciences Graduate Program, Trent University, Peterborough, Ontario, Canada
}

\begin{abstract}
Phenotypic plasticity is one of the traits often associated with successful invasive species, providing each individual with a unique ability to adapt to novel environments. The aim of the present study was to evaluate the morphological plasticity of Lepomis gibbosus, a successful invader outside of its native North American range, across the latitudinal extent of the species' introduced European range to determine whether or not climate, using latitude as a surrogate of thermal conditions, has an underlying influence on the species' morphology and consequently its invasiveness potential. Five characters (body depth, dorsal, ventral and pelvic fins, and eye diameter) differed significantly among the populations, and in particular the Slovakian population, with a significant effect of latitude on five other characters (maxilla length, pre-dorsal, pre-ventral, pre-orbital distances, and caudal peduncle length), which distinguished the various populations and distinguished the Portuguese population from the rest. The results suggest considerable morphological plasticity in L. gibbosus, with two different patterns of development that can reflect to different allocation of sources as well as different stage of invasion process.
\end{abstract}

Keywords: phenotypic plasticity / Lepomis gibbosus / latitudinal effect / morphology

Résumé - Est-ce que la latitude influence la plasticité phénotypique des traits morphologiques dans les populations de perche soleil non indigène d'Europe? La plasticité phénotypique est l'un des traits souvent associés à des espèces envahissantes, offrant à chaque individu une capacité unique à s'adapter à de nouveaux environnements. L'objectif de la présente étude était d'évaluer la plasticité morphologique de Lepomis gibbosus, un envahisseur performant en dehors de son aire nord-américaine native, dans l'étendue latitudinale de la répartition européenne de l'espèce introduite pour déterminer si le climat, en utilisant la latitude en tant que proxy des conditions thermiques, a une influence sous-jacente sur la morphologie de l'espèce et par conséquent son potentiel d'invasion. Cinq caractères (hauteur du corps, nageoires dorsale, ventrale et pelvienne et diamètre de l'œil) diffèrent significativement parmi les populations, et en particulier la population slovaque, avec un effet significatif de la latitude sur cinq autres caractères (longueur du maxillaire, distances pré-dorsale, pré-ventrale, pré-orbitale et longueur du pédoncule caudal), qui distingue les différentes populations et la population portugaise du reste. Les résultats suggèrent une plasticité morphologique considérable chez L. gibbosus, avec deux modèles de développement différents qui peuvent être liés à une répartition des ressources différente ainsi qu'à différents stades de processus d'invasion.

Mots-clés : plasticité phénotypique / Lepomis gibbosus / effet latitudinal / morphologie

\section{Introduction}

The ability of an introduced species to adapt and make use of the available resources in a novel environment plays an

\footnotetext{
${ }^{*}$ Corresponding author: zahorskae@fns.uniba.sk
}

important role in determining its invasion success (Sakai et al., 2001). There are several traits essential for successful invasion, and these are usually connected with phenotypic plasticity, which reflects the potential of a species to adapt to novel conditions. Successful invaders are able to switch between alternative developmental trajectories and/or react quickly 
Table 1. Country, site code, site name, latitude and longitude (in GPS coordinates), and number ( $n$ ) of specimens of pumpkinseed Lepomis gibbosus from each population in European inland waters.

\begin{tabular}{|c|c|c|c|c|c|}
\hline Country & Code & Site name & Latitude & Longitude & $n$ \\
\hline \multirow[t]{2}{*}{ Netherlands } & NSP & Schoapedobbe Pond & $52.951944 \mathrm{~N}$ & $6.258333 \mathrm{E}$ & 53 \\
\hline & NMP & Meeuwven Pond & $51.391111 \mathrm{~N}$ & $5.499722 \mathrm{E}$ & 98 \\
\hline \multirow[t]{5}{*}{ England } & ELC & Cottesmore Lower Pond & $51.089046 \mathrm{~N}$ & $0.219408 \mathrm{~W}$ & 95 \\
\hline & EUC & Cottesmore Upper Pond & $51.088147 \mathrm{~N}$ & $0.219443 \mathrm{~W}$ & 100 \\
\hline & ECS & Cottesmore School Pond & $51.087248 \mathrm{~N}$ & $0.219477 \mathrm{~W}$ & 100 \\
\hline & E6T & Tanyard Fishery Pond No. 6 & $51.024187 \mathrm{~N}$ & $0.009114 \mathrm{E}$ & 100 \\
\hline & EBS & Batts Bridge Stream & $51.019472 \mathrm{~N}$ & $0.073074 \mathrm{E}$ & 66 \\
\hline \multirow[t]{2}{*}{ Belgium } & BWP & Webbekomsbroek Pond & $50.968333 \mathrm{~N}$ & $5.076667 \mathrm{E}$ & 147 \\
\hline & BSS & Slangebeek Stream & $50.956111 \mathrm{~N}$ & $5.302778 \mathrm{E}$ & 74 \\
\hline Slovakia & $\mathrm{SCN}$ & Čunovo & $48.031436 \mathrm{~N}$ & 17.229953E & 171 \\
\hline \multirow[t]{2}{*}{ France } & FBM & Brière Marsh & $47.366111 \mathrm{~N}$ & $2.312500 \mathrm{~W}$ & 111 \\
\hline & FGL & Grand-Lieu Lake & $47.083333 \mathrm{~N}$ & $1.650000 \mathrm{~W}$ & 95 \\
\hline \multirow[t]{5}{*}{ Portugal } & PMN & MonteNovo & $38.3044 \mathrm{~N}$ & $7.4237 \mathrm{~W}$ & 172 \\
\hline & PM & Montargil & $39.0503 \mathrm{~N}$ & $8.1789 W$ & 181 \\
\hline & PF & Fratel & $39.3235 \mathrm{~N}$ & $7.4810 \mathrm{~W}$ & 166 \\
\hline & PB & Belver & $39.4794 \mathrm{~N}$ & $7.9969 \mathrm{~W}$ & 129 \\
\hline & PR & Régua & $41.1422 \mathrm{~N}$ & $7.7080 \mathrm{~W}$ & 251 \\
\hline
\end{tabular}

(in phenotypic terms) to local conditions, which includes the absence of (or release from) native competitors, diseases, or predators (e.g. Alpert, 2006; Kováč, 2011). Amongst the most important biological traits that demonstrate plasticity are: fecundity, age and length at maturity (e.g. Copp and Fox, 2007), and morphology (Copp et al., 2002; Lavrinčíková et al., 2005; Tomeček et al., 2005; Záhorská et al., 2009). There are several invasive freshwater fishes that support this assumption, including pumpkinseed Lepomis gibbosus (Tomeček et al., 2005), topmouth gudgeon Pseudorasbora parva (Záhorská et al., 2009), and round goby Neogobius melanastomus (L'avrinčíková et al., 2005). Pumpkinseed, a freshwater sunfish (Centrarchidae) native to North American, was introduced intentionally or unintentionally into European inland waters during the 19th and 20th centuries (Copp and Fox, 2007). After some initial difficulties in establishing self-sustaining populations, e.g. in France (Künstler, 1908), the species subsequently established itself in most locations where it was introduced, spreading in many cases into adjacent waters with or without human intervention (Copp and Fox, 2007). As a consequence, it is a species with amongst the highest rates of successful establishment in Europe (García-Berthou et al., 2005).

Following an initial, exploratory examination of a relationship between pumpkinseed morphological characters and latitude (Copp et al., 2002), subsequent studies in Iberia demonstrated morphological differences in pumpkinseed populations that correspond to broad habitat types (Bhagat et al., 2006, 2011a) rather than geographic regions (Canada vs. Central Europe), and this suggests that this species has a high degree of developmental plasticity in morphology under ambient (Tomeček et al., 2005) as well as artificially heated conditions (Šumer et al., 2005). And in its native range, the pumpkinseed's morphology varies according to its trophic position, habitat use, presence/absence of predator (Robinson and Wilson, 1996) and water flow (river vs. lake; Brinsmead and Fox, 2002). Differences in mouth morphology in two reservoir populations of introduced L. gibbosus in Greece have been linked to their different diets (Bobori et al., 2006).

In Europe, Copp et al. (2002) provided the morphological data for L. gibbosus in the first study of the species in England, and using data from earlier morphological studies for elsewhere in Europe (Sedlár, 1957; Tandon, 1976, 1977) to undertake a preliminary test the hypothesis that some morphological characters (caudal-peduncle length, dorsal fin length and depth) varied with latitude. In view of the low number of populations $(n=4)$ around Europe, Copp et al. (2002) noted the possibility that the observed patterns may be due to growth variability rather than to different environments. Since then, these hypothesised relationships with latitude have not been further investigated. Thus, the aims of the present study were to: (1) assess the morphological characters of nonnative $L$. gibbosus populations from water bodies and water courses from across the Europe ( 6 countries, 17 localities) and (2) to re-assess the hypotheses of Copp et al. (2002) that some morphological characters vary as a function of geographical location (latitude).

\section{Methods}

Fish were collected from 17 locations across Europe (Tab. 1). In England, fish were collected from five locations: (i) Cottesmore School Pond (ECS; $n=100$ ), the headwater of the Buchan Stream system (Pease Pottage, West Sussex, England, UK), which is believed to be one of the first water bodies in England into which L. gibbosus were introduced in the late 1890s or early 1900s (Copp et al., 2002). Originally an ornamental pond, ECS is a reservoir fed by a chalk spring located about $20 \mathrm{~m}$ upstream. ECS' outflow feeds a small stream, which meanders a short distance before discharging into; (ii) Cottesmore Upper 
Table 2a. Mean values of morphological characters in pumpkinseed from European inland waters (see Tab. 1 for study site codes).

\begin{tabular}{|c|c|c|c|c|c|c|c|c|c|c|c|c|c|}
\hline & Study site & NSP & NMP & ELC & EUC & ECS & E6T & EBS & BWP & BSS & $\mathrm{SCN}$ & FBM & FGL \\
\hline & Standard length (SL) & 122.7 & 66.6 & 62.2 & 65.2 & 60.4 & 95.0 & 67.7 & 60.6 & 47.9 & 64.67 & 89.5 & 65.3 \\
\hline & In $\%$ of $\mathrm{SL}$ & & & & & & & & & & & & \\
\hline 1 & Head length & 34.3 & 35.7 & 35.2 & 34.6 & 33.4 & 35.0 & 36.0 & 34.8 & 34.0 & 36.3 & 37.9 & 35.9 \\
\hline 2 & Pre-orbital distance & 5.8 & 6.1 & 6.2 & 6.1 & 6.0 & 6.2 & 7.4 & 6.5 & 6.3 & 7.1 & 7.2 & 6.7 \\
\hline 3 & Eye diameter & 7.8 & 11.3 & 10.9 & 9.7 & 9.8 & 9.0 & 10.0 & 10.3 & 10.4 & 11.3 & 9.6 & 10.5 \\
\hline 4 & Post-orbital distance & 21.1 & 18.8 & 18.4 & 18.9 & 17.6 & 20.4 & 18.8 & 18.1 & 17.5 & 18.4 & 21.3 & 19.1 \\
\hline 5 & Maxilla length & 8.1 & 8.1 & 9.3 & 8.5 & 8.6 & 9.3 & 9.4 & 8.8 & 7.2 & 7.9 & 10.3 & 9.6 \\
\hline 6 & Head depth & 37.0 & 34.3 & 34.7 & 31.3 & 33.5 & 36.7 & 36.0 & 32.9 & 32.2 & 32.7 & 39.3 & 37.7 \\
\hline 7 & Pre-dorsal distance & 42.6 & 43.4 & 42.8 & 42.2 & 41.1 & 45.4 & 43.4 & 43.6 & 42.9 & 43.5 & 44.1 & 44.5 \\
\hline 8 & Pre-ventral distance & 43.3 & 42.9 & 41.9 & 41.5 & 41.6 & 44.1 & 43.1 & 42.5 & 42.6 & 43.4 & 44.7 & 43.7 \\
\hline 9 & Pre-anal distance & 67.6 & 65.3 & 63.2 & 63.6 & 63.5 & 66.4 & 63.9 & 64.6 & 63.9 & 64.4 & 67.5 & 66.0 \\
\hline 10 & Pectoral (P)-ventral (V) distance & 17.5 & 15.4 & 14.7 & 14.4 & 13.9 & 17.0 & 16.0 & 15.0 & 13.8 & 15.3 & 17.3 & 16.2 \\
\hline 11 & Ventral (V)-anal (A) distance & 27.7 & 25.3 & 23.7 & 24.5 & 24.4 & 25.4 & 23.6 & 24.7 & 23.9 & 23.0 & 25.3 & 24.7 \\
\hline 12 & Body depth & 49.9 & 44.5 & 41.4 & 41.5 & 41.4 & 49.9 & 43.6 & 44.4 & 40.3 & 41.4 & 49.2 & 46.8 \\
\hline 13 & Caudal (C) peduncle length & 20.8 & 22.7 & 22.5 & 22.3 & 22.6 & 21.1 & 22.0 & 22.1 & 22.8 & 21.8 & 20.0 & 21.2 \\
\hline 14 & Caudal (C) peduncle depth & 20.6 & 19.2 & 18.8 & 19.4 & 19.7 & 20.8 & 19.9 & 20.9 & 19.8 & 19.5 & 21.2 & 21.7 \\
\hline 15 & Min body depth & 14.4 & 13.0 & 13.3 & 13.3 & 13.4 & 14.3 & 14.0 & 14.2 & 13.5 & 14.3 & 14.9 & 14.3 \\
\hline 16 & Caudal (C) base fin length & 17.1 & 15.3 & 15.9 & 16.0 & 15.5 & 15.4 & 17.3 & 15.8 & 15.2 & 16.3 & 17.1 & 16.9 \\
\hline 17 & Dorsal (D) fin length & 50.9 & 45.9 & 46.2 & 46.9 & 46.5 & 49.3 & 47.0 & 47.0 & 44.6 & 45.8 & 51.0 & 48.4 \\
\hline 18 & Anal (A) fin length & 21.6 & 19.1 & 20.0 & 19.9 & 20.0 & 21.4 & 20.9 & 20.7 & 19.7 & 20.4 & 22.6 & 21.5 \\
\hline 19 & Pectoral $(\mathrm{P})$ fin length & 26.6 & 27.0 & 27.1 & 25.0 & 25.6 & 29.9 & 26.3 & 24.1 & 22.8 & 30.4 & 26.7 & 24.5 \\
\hline 20 & Pectoral (P) base length & 7.4 & 23.1 & 6.5 & 6.3 & 6.3 & 7.7 & 7.0 & 6.5 & 6.1 & 7.8 & 7.4 & 7.0 \\
\hline 21 & Ventral (V) fin length & 22.6 & 15.4 & 22.4 & 21.6 & 21.1 & 24.2 & 22.1 & 21.3 & 19.8 & 20.5 & 22.3 & 20.8 \\
\hline 22 & Caudal (C) fin length & 24.8 & 29.7 & 30.1 & 28.7 & 30.1 & 26.4 & 29.4 & 26.9 & 27.7 & 28.8 & 28.0 & 27.5 \\
\hline 23 & Dorsal (D) fin1 depth & 13.6 & 16.4 & 14.8 & 14.0 & 14.1 & 15.8 & 15.5 & 15.7 & 14.4 & 10.7 & 14.9 & 13.9 \\
\hline 24 & Dorsal (D) fin2 depth & 17.2 & 17.4 & 17.2 & 17.6 & 17.4 & 17.6 & 17.5 & 16.5 & 15.7 & 16.0 & 18.3 & 16.7 \\
\hline 25 & Anal (A) fin depth & 15.8 & 16.3 & 17.3 & 17.6 & 17.1 & 17.1 & 17.8 & 15.9 & 14.6 & 15.5 & 17.5 & 17.0 \\
\hline
\end{tabular}

Pond (EUC; $n=100)$, which itself discharges via a short stream into; (iii) Cottesmore Lower Pond (ELC; $n=95$ ). EUC and ELC are artificial "water hazards" constructed circa 2001 on the Cottesmore GolfCourse, which encircles ECS (Fox et al., 2011); (iv) Cackle Street (EBS; $n=66)$ is a stretch of Batts Bridge Stream in East Sussex situated just downstream of a commercial angling lake (see Fobert et al., 2013); and (v) a commercial angling pond, Tanyards Lake 6 (E6T; $n=100)$, which is situated near Danehill, East Sussex. For geographic location details, see Villeneuve et al. (2005).

Three locations in Western Europe were included. In the Netherlands, L. gibbosus were sampled in Schoapedobbe Pond (NSP; $n=53$ ) and in Meeuwven Pond (NMP; $n=98$ ). Two sites located in Flanders, in the northeast of Belgium, were sampled: Slangebeek Stream (BSS; $n=74)$, a small tributary of the River Demer; and Webbekomsbroek Pond (BWP; $n=147$ ), an artificial water body with characteristics of near-natural floodplain ponds (Van Thuyne and Breine, 2005). In France, two sites in the River Loire drainage basin (northwest France) were sampled: Brière Marsh (FBM; $n=111)$, a freshwater wetland system composed of a complex network of permanently-flooded canals (Cucherousset et al., 2006) and Grand-Lieu Lake (FGL; $n=95$ ), a large, shallow, naturally turbid and eutrophic lake (Paillisson and Marion, 2006). For geographic location details of these western European sites, see Cucherousset et al. (2009).
Six further sites, one in Central Europe (Slovakia) and five in Southern Europe (Portugal) were also sampled. In southern Slovakia, L. gibbosus were collected from a densely-vegetated, former gravel-pit ( area $=15 \mathrm{ha}$; maximum depth $=5 \mathrm{~m})$ in the River Danube flood plain, Vel'ké Čunovo (SCN; $n=171)$. The Portuguese sites consisted of five artificial water bodies: (i) Belver Reservoir (PB; $n=129)$, a lowland reservoir with a "sinuous" shoreline with many small littoral areas containing a mix of emergent and submersed vegetation that is located on the main channel of the River Tejo; (ii) Montargil Reservoir (PM; $n=181$ ), an off-stream water storage reservoir created primarily for irrigation that is situated adjacent to the River Tejo River; (iii) Régua Reservoir (PR; $n=251$ ), situated in the main channel of the River Douro and has a relatively extensive pelagic habitat (Bhagat et al., 2006); (iv) Monte Novo Reservoir (PMN), located on the River Guadiana (the southern frontier between Spain and Portugal), which is fed by three connecting tributaries and is primarily used as a source of irrigation in the region. It has a circular morphometry with gentle slope banks and a bottom dominated by fine sediments, resulting in well developed littoral areas, colonized mostly by emergent macrophytes and floating vegetation; and (v) Fratel Reservoir (PF), located in the main course of the River Tejo and has a narrow and elongated morphometry, with steep banks containing an incipient littoral zone. PF runs through constrained, V-shaped valleys and is delimited by another 
Table 2b. Mean values of morphological characters in pumpkinseed from water bodies in Portugal (see Tab. 1 for study site codes).

\begin{tabular}{|c|c|c|c|c|c|c|}
\hline & Study site & PB & PM & PR & PMN & $\mathrm{PF}$ \\
\hline & Standard length (SL) & 85.74 & 78.48 & 79.94 & 72.38 & 83.93 \\
\hline & In $\%$ of $\mathrm{SL}$ & & & & & \\
\hline 1 & Head length & 35.66 & 35.07 & 35.10 & 34.36 & 36.34 \\
\hline 2 & Pre-orbital distance & 9.61 & 9.95 & 9.88 & 10.58 & 10.74 \\
\hline 3 & Eye diameter & 10.27 & 10.03 & 10.32 & - & 11.22 \\
\hline 5 & Maxilla length & 10.82 & 10.52 & 10.59 & 10.65 & 41.53 \\
\hline 7 & Pre-dorsal distance & 40.64 & 41.10 & 40.79 & 40.25 & 40.24 \\
\hline 8 & Pre-ventral distance & 40.20 & 40.08 & 39.58 & 39.21 & 43.67 \\
\hline 12 & Body depth & 43.51 & 41.37 & 43.03 & 42.38 & 47.18 \\
\hline 13 & C-peduncle length & 48.50 & 47.01 & 47.96 & 47.28 & 20.20 \\
\hline 16 & C-base fin length & 21.16 & 20.60 & 21.09 & 20.91 & 19.70 \\
\hline 17 & D-fin length & 19.78 & 19.71 & 19.71 & 19.33 & 14.22 \\
\hline 18 & A-fin length & 14.35 & 14.15 & 14.45 & 14.23 & 14.22 \\
\hline 19 & P-fin length & 28.18 & 27.95 & 28.79 & - & 30.47 \\
\hline 20 & P-base length & 6.75 & 6.66 & 6.70 & 6.64 & 6.74 \\
\hline 21 & V-fin length & 23.25 & 22.48 & 23.21 & 22.63 & 24.63 \\
\hline
\end{tabular}

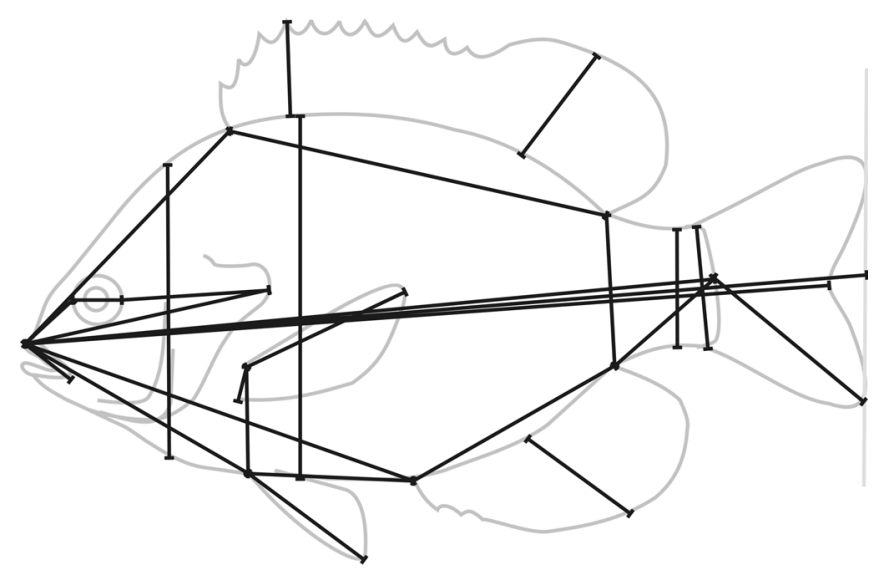

Fig. 1. Scheme of morphometric characters for distance-based measurements (Tab. 2a) taken from pumpkinseed.

reservoir located upstream. For further details on these locations, see Bhagat et al. (2011b).

Specimens were collected during the respective spawning periods of the populations (mainly from mid-May to early July) by various means (electrofishing, netting, funnel trapping, and angling): in Belgium, England, France and the Netherlands in 2006 (Cucherousset et al., 2009); in Portugal during 2004-2007 (Bhagat et al., 2011b). Captured fish were immediately killed by an overdose of anaesthetic and placed in a slurry of ice water and chilled to freezing for storage.

In the laboratory, the specimens were defrosted and 26 mensural characters (Fig. 1), including standard length (SL), were immediately measured (except for specimens from Portugal with 14 characters) from digital photographs taken by a Nikon CoolPix 5000 camera using the IMPOR 2.31E software. Specimens from Portugal were measured with UltraCal Mark III digital calliper (Accuracy $40 \mu \mathrm{m}$; Fowler Co., Inc., Newton, MA, USA). Significant differences between the measurement methods were not observed (paired $T$-test). To examine patterns of relative growth, raw data from morphometric characters were plotted against SL as described by Kováč et al. (1999). Triple regression analysis (TRA) was used to test whether body proportions change abruptly rather than gradually (Kováč et al., 1999) based on the three possible growth patterns (isometric, allometric and isometric with abrupt change). The analysis tests primarily the null hypothesis characterized by isometric growth with a straight line with positive slope. If the hypothesis is rejected, then the alternative hypotheses are analysed. Allometric growth is characterized by a non-linear relationship between the character and SL represented by quadratic curve (concave upwards or downwards). Growth that demonstrates abrupt change was characterized by the presence of two linear lines separated with a gape - a breakpoint. We fitted simple linear, quadratic and split-linear regression models to plots of the dependent variables against SL, and tested them for significant improvements in fit over the simple linear model. The growth with abrupt change was only accepted if the split linear fit was significantly better than both the simple linear and quadratic fits (Kováč et al., 1999).

Single-factor ANOVA was used to test for differences among populations of L. gibbosus for 14 mensural characters (those measured in all populations examined, including Portuguese populations) as well as singular traits connected with habitat type (littoral vs. pelagic and riverine $v s$. lacustrine). Tukey's HSD post-hoc test was used to determine which populations were differentiated for each of the variables.

In view of the spatial proximity of five Portuguese populations established under a range of conditions, the discriminant functional analysis (DFA) was used to determine its effect on overall similarity/difference between populations in the context of different habitats. Correlation analysis with Pearson correlation coefficient was used to test for the correlation of characters with standard length (SL), latitude (LAT) and longitude (LONG). 
Table 3a. Linear (L), quadratic (Q) and split linear (S) regression codes for morphometric character in pumpkinseed from European inland waters (see Tab. 1 for study site codes).

\begin{tabular}{|c|c|c|c|c|c|c|c|c|c|c|c|c|c|}
\hline & Study site & NSP & NMP & ELC & EUC & ECS & E6T & EBS & BWP & BSS & $\mathrm{SCN}$ & FBM & FGL \\
\hline 1 & Head length & $\mathrm{L}$ & $\mathrm{L}$ & $\mathrm{L}$ & $\mathrm{L}$ & $\mathrm{S}$ & $\mathrm{L}$ & S & $\mathrm{S}$ & $\mathrm{L}$ & $\mathrm{L}$ & $\mathrm{L}$ & $\mathrm{L}$ \\
\hline 2 & Pre-orbital distance & Q & $\mathrm{L}$ & $\mathrm{L}$ & $\mathrm{L}$ & $\mathrm{S}$ & $\mathrm{S}$ & $\mathrm{L}$ & $\mathrm{S}$ & $\mathrm{L}$ & $\mathrm{L}$ & $\mathrm{L}$ & $\mathrm{L}$ \\
\hline 3 & Eye diameter & $\mathrm{L}$ & $\mathrm{L}$ & $\mathrm{S}$ & $\mathrm{L}$ & Q & Q & Q & $\mathrm{L}$ & $\mathrm{L}$ & $\mathrm{Q}$ & Q & $\mathrm{L}$ \\
\hline 4 & Post-orbital distance & $\mathrm{L}$ & $\mathrm{L}$ & $\mathrm{L}$ & Q & $\mathrm{S}$ & $\mathrm{S}$ & Q & $\mathrm{S}$ & $\mathrm{L}$ & $\mathrm{L}$ & Q & $\mathrm{L}$ \\
\hline 5 & Maxilla length & $\mathrm{L}$ & $\mathrm{L}$ & $\mathrm{L}$ & Q & $\mathrm{L}$ & $\mathrm{L}$ & $\mathrm{L}$ & $\mathrm{L}$ & Q & $\mathrm{L}$ & $\mathrm{L}$ & $\mathrm{L}$ \\
\hline 6 & Head depth & $\mathrm{L}$ & $\mathrm{L}$ & Q & $\mathrm{S}$ & $\mathrm{Q}$ & $\mathrm{L}$ & $\mathrm{L}$ & $\mathrm{S}$ & $\mathrm{L}$ & $\mathrm{L}$ & S & Q \\
\hline 7 & Pre-dorsal distance & $\mathrm{L}$ & $\mathrm{L}$ & $\mathrm{L}$ & $\mathrm{L}$ & $\mathrm{L}$ & $\mathrm{L}$ & $\mathrm{L}$ & Q & $\mathrm{L}$ & $\mathrm{L}$ & Q & $\mathrm{S}$ \\
\hline 8 & Pre-ventral distance & $\mathrm{L}$ & $\mathrm{L}$ & $\mathrm{L}$ & $\mathrm{L}$ & $\mathrm{L}$ & $\mathrm{L}$ & $\mathrm{L}$ & $\mathrm{L}$ & $\mathrm{L}$ & $\mathrm{L}$ & Q & $\mathrm{L}$ \\
\hline 9 & Pre-anal distance & $\mathrm{L}$ & $\mathrm{L}$ & Q & $\mathrm{L}$ & $\mathrm{S}$ & $\mathrm{S}$ & $\mathrm{Q}$ & Q & $\mathrm{L}$ & $\mathrm{L}$ & $\mathrm{S}$ & $\mathrm{L}$ \\
\hline 10 & $\mathrm{P}-\mathrm{V}$ distance & $\mathrm{L}$ & $\mathrm{L}$ & Q & $\mathrm{L}$ & $\mathrm{S}$ & $\mathrm{L}$ & $\mathrm{S}$ & $\mathrm{L}$ & $\mathrm{L}$ & $\mathrm{L}$ & Q & $\mathrm{L}$ \\
\hline 11 & $\mathrm{~V}-\mathrm{A}$ distance & $\mathrm{L}$ & $\mathrm{L}$ & $\mathrm{L}$ & $\mathrm{S}$ & $\mathrm{S}$ & $\mathrm{S}$ & Q & $\mathrm{Q}$ & $\mathrm{L}$ & $\mathrm{L}$ & Q & $\mathrm{L}$ \\
\hline 12 & Body depth & $\mathrm{L}$ & $\mathrm{L}$ & $\mathrm{L}$ & $\mathrm{L}$ & $\mathrm{S}$ & $\mathrm{L}$ & $\mathrm{L}$ & $\mathrm{S}$ & $\mathrm{L}$ & $\mathrm{Q}$ & $\mathrm{S}$ & $\mathrm{L}$ \\
\hline 13 & C-peduncle length & $\mathrm{L}$ & Q & Q & $\mathrm{L}$ & $\mathrm{S}$ & $\mathrm{L}$ & Q & $\mathrm{S}$ & $\mathrm{L}$ & $\mathrm{L}$ & $\mathrm{L}$ & $\mathrm{L}$ \\
\hline 14 & C-peduncle depth & $\mathrm{L}$ & $\mathrm{L}$ & Q & $\mathrm{L}$ & Q & $\mathrm{L}$ & $\mathrm{L}$ & $\mathrm{L}$ & $\mathrm{L}$ & $\mathrm{L}$ & $\mathrm{L}$ & $\mathrm{L}$ \\
\hline 15 & Min body depth & $\mathrm{L}$ & $\mathrm{L}$ & $\mathrm{L}$ & $\mathrm{Q}$ & Q & $\mathrm{L}$ & $\mathrm{L}$ & $\mathrm{L}$ & $\mathrm{L}$ & $\mathrm{L}$ & $\mathrm{L}$ & $\mathrm{S}$ \\
\hline 16 & C-base fin length & $\mathrm{L}$ & $\mathrm{Q}$ & $\mathrm{L}$ & $\mathrm{L}$ & $\mathrm{Q}$ & $\mathrm{L}$ & $\mathrm{Q}$ & $\mathrm{Q}$ & $\mathrm{S}$ & $\mathrm{S}$ & $\mathrm{Q}$ & $\mathrm{S}$ \\
\hline 17 & D-fin length & $\mathrm{L}$ & $\mathrm{L}$ & $\mathrm{S}$ & $\mathrm{L}$ & Q & $\mathrm{S}$ & $\mathrm{L}$ & Q & $\mathrm{L}$ & $\mathrm{L}$ & $\mathrm{L}$ & $\mathrm{L}$ \\
\hline 18 & A-fin length & $\mathrm{L}$ & $\mathrm{L}$ & $\mathrm{L}$ & $\mathrm{L}$ & $\mathrm{S}$ & Q & Q & $\mathrm{L}$ & $\mathrm{L}$ & $\mathrm{Q}$ & $\mathrm{L}$ & $\mathrm{S}$ \\
\hline 19 & P-fin length & $\mathrm{L}$ & $\mathrm{L}$ & $\mathrm{L}$ & $\mathrm{L}$ & $\mathrm{L}$ & $\mathrm{L}$ & $\mathrm{L}$ & Q & $\mathrm{L}$ & $\mathrm{S}$ & $\mathrm{S}$ & Q \\
\hline 20 & P-base length & $\mathrm{L}$ & $\mathrm{L}$ & $\mathrm{L}$ & Q & $\mathrm{S}$ & $\mathrm{L}$ & $\mathrm{L}$ & $\mathrm{L}$ & $\mathrm{L}$ & $\mathrm{Q}$ & $\mathrm{L}$ & $\mathrm{L}$ \\
\hline 21 & V-fin length & $\mathrm{S}$ & $\mathrm{L}$ & $\mathrm{L}$ & $\mathrm{L}$ & Q & $\mathrm{L}$ & $\mathrm{S}$ & $\mathrm{S}$ & $\mathrm{L}$ & $\mathrm{Q}$ & Q & $\mathrm{L}$ \\
\hline 22 & C-fin length & $\mathrm{L}$ & $\mathrm{L}$ & $\mathrm{L}$ & $\mathrm{L}$ & Q & $\mathrm{L}$ & Q & $\mathrm{S}$ & $\mathrm{L}$ & $\mathrm{Q}$ & $\mathrm{L}$ & $\mathrm{L}$ \\
\hline 23 & D-fin1 depth & $\mathrm{S}$ & $\mathrm{L}$ & $\mathrm{L}$ & $\mathrm{L}$ & Q & $\mathrm{S}$ & Q & $\mathrm{L}$ & Q & Q & $\mathrm{L}$ & Q \\
\hline 24 & D-fin2 depth & $\mathrm{L}$ & $\mathrm{L}$ & $\mathrm{L}$ & $\mathrm{L}$ & $\mathrm{Q}$ & $\mathrm{L}$ & $\mathrm{L}$ & Q & $\mathrm{L}$ & $\mathrm{L}$ & $\mathrm{L}$ & $\mathrm{L}$ \\
\hline 25 & A-fin depth & $\mathrm{L}$ & $\mathrm{L}$ & $\mathrm{Q}$ & $\mathrm{L}$ & $\mathrm{L}$ & $\mathrm{L}$ & $\mathrm{S}$ & $\mathrm{Q}$ & $\mathrm{S}$ & $\mathrm{L}$ & $\mathrm{Q}$ & $\mathrm{S}$ \\
\hline
\end{tabular}

Table 3b. Linear $(\mathrm{L})$, quadratic $(\mathrm{Q})$ and split linear $(\mathrm{S})$ regression codes for morphometric characters in pumpkinseed from water bodies in Portugal (see Tab. 1 for study site codes).

\begin{tabular}{|c|c|c|c|c|c|c|}
\hline & Character & $\mathrm{PB}$ & PM & PR & PMN & $\mathrm{PF}$ \\
\hline 1 & Head length & $\mathrm{S}$ & $\mathrm{L}$ & $\mathrm{L}$ & $\mathrm{L}$ & $\mathrm{L}$ \\
\hline 2 & Pre-orbital distance & $\mathrm{L}$ & Q & $\mathrm{L}$ & $\mathrm{L}$ & $\mathrm{L}$ \\
\hline 3 & Eye diameter & $\mathrm{Q}$ & $\mathrm{L}$ & $\mathrm{L}$ & - & $\mathrm{L}$ \\
\hline 4 & Post-orbital distance & - & - & - & - & - \\
\hline 5 & Length of maxilla & $\mathrm{Q}$ & $\mathrm{L}$ & $\mathrm{L}$ & $\mathrm{L}$ & $\mathrm{Q}$ \\
\hline 6 & Head depth & - & - & - & - & - \\
\hline 7 & Pre-dorsal distance & $\mathrm{Q}$ & $\mathrm{L}$ & $\mathrm{L}$ & $\mathrm{L}$ & $\mathrm{L}$ \\
\hline 8 & Pre-ventral distance & $\mathrm{Q}$ & $\mathrm{Q}$ & $\mathrm{L}$ & $\mathrm{L}$ & $\mathrm{L}$ \\
\hline 9 & Pre-anal distance & - & - & - & - & - \\
\hline 10 & $\mathrm{P}-\mathrm{V}$ distance & - & - & - & - & - \\
\hline 11 & V-A distance & - & - & - & - & - \\
\hline 12 & Body depth & $\mathrm{L}$ & $\mathrm{S}$ & Q & $\mathrm{L}$ & $\mathrm{L}$ \\
\hline 13 & C-peduncle length & $\mathrm{Q}$ & $\mathrm{L}$ & $\mathrm{Q}$ & $\mathrm{Q}$ & $\mathrm{L}$ \\
\hline 14 & C-peduncle depth & - & - & - & - & - \\
\hline 15 & Min body depth & - & - & - & - & - \\
\hline 16 & $\mathrm{C}$-base fin length & Q & $\mathrm{L}$ & $\mathrm{L}$ & $\mathrm{L}$ & $\mathrm{Q}$ \\
\hline 17 & D-fin length & $\mathrm{L}$ & $\mathrm{L}$ & $\mathrm{L}$ & $\mathrm{L}$ & $\mathrm{L}$ \\
\hline 18 & A-fin length & $\mathrm{S}$ & $\mathrm{L}$ & $\mathrm{L}$ & $\mathrm{L}$ & $\mathrm{Q}$ \\
\hline 19 & P-fin length & $\mathrm{S}$ & $\mathrm{S}$ & $\mathrm{L}$ & - & $\mathrm{L}$ \\
\hline 20 & P-base length & $\mathrm{L}$ & $\mathrm{L}$ & $\mathrm{L}$ & $\mathrm{L}$ & $\mathrm{S}$ \\
\hline 21 & V-fin length & Q & $\mathrm{L}$ & $\mathrm{L}$ & Q & Q \\
\hline 22 & $\mathrm{C}$-fin length & - & - & - & - & - \\
\hline 23 & D-fin1 depth & - & - & - & - & - \\
\hline 24 & D-fin2 depth & - & - & - & - & - \\
\hline 25 & A-fin depth & - & - & - & - & - \\
\hline
\end{tabular}


Table 4. Correlation based on correlation analysis of each trait toward standard length and latitude for all populations. Significant differences are in boldface.

\begin{tabular}{lcr}
\hline Morphological trait & Standard length & Latitude \\
\hline Head length & 0.18 & 0.00 \\
Pre-orbital distance & 0.27 & $\mathbf{- 0 . 8 9}$ \\
Eye diameter & $\mathbf{- 0 . 5 6}$ & 0.05 \\
Maxilla length & 0.31 & $\mathbf{- 0 . 6 8}$ \\
Pre-dorsal distance & 0.04 & $\mathbf{0 . 5 6}$ \\
Pre-ventral distance & 0.00 & $\mathbf{0 . 6 4}$ \\
Body depth & $\mathbf{0 . 6 6}$ & 0.13 \\
D-fin length & $\mathbf{0 . 6 5}$ & -0.12 \\
A-fin length & $\mathbf{0 . 3 5}$ & -0.16 \\
C-peduncle length & -0.26 & $\mathbf{0 . 6 6}$ \\
C-base fin length & 0.17 & $\mathbf{0 . 5 1}$ \\
P-fin length & $\mathbf{0 . 4 1}$ & -0.30 \\
P-base length & 0.27 & 0.05 \\
V-fin length & $\mathbf{0 . 4 8}$ & -0.29 \\
\hline
\end{tabular}

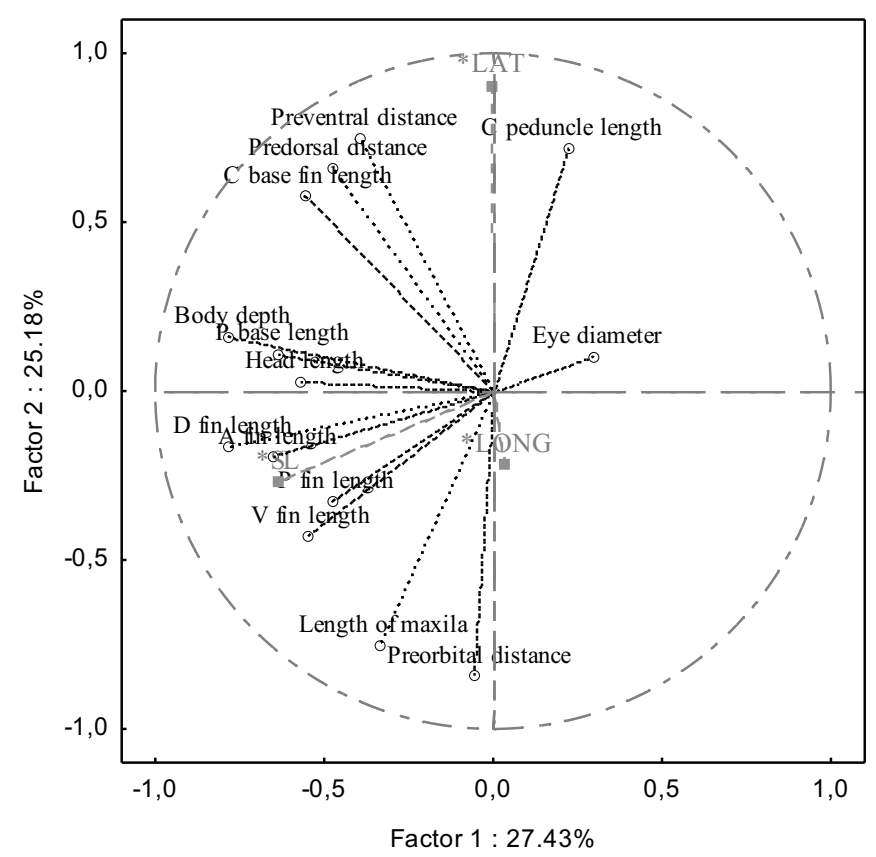

Fig. 2. Principle component analysis plot (PCA) of measured characters distribution with three additional supplementary variables (LAT - latitude, LONG - longitude, and SL - standard length) in pumpkinseed from different sites. The two dimensions of the PCA plot represent $53 \%$ of the data variability of first two factors resulted from PCA (C - caudal, P - pectoral, V - ventral, D - dorsal, and A - anal).

Principal component analysis (PCA) was used to explore the best combinations of variable groups explaining total variability among the populations. In PCA, analysis of 14 characters were used, with SL, LAT and LONG as supplementary variables. DFA was performed consequently particularly on variables significantly correlating with SL and
Table 5. Canonical loadings (i.e. correlations) for all populations between morphological traits and each canonical axis in the overall discriminant functional analysis (DFA) concerning the effect of latitude. Traits with correlations that are greater than or equal to an absolute value of 0.4 are considered to have biologically significant relationships (in boldface; McGarigal et al., 2000).

\begin{tabular}{lrr}
\hline \multicolumn{3}{c}{ Discriminant functional analysis } \\
\hline Morphometric characters & Axis 1 & Axis 2 \\
\hline Pre-orbital distance & $\mathbf{0 . 6 2 9}$ & 0.128 \\
Maxilla length & 0.351 & $\mathbf{0 . 7 1 0}$ \\
Pre-dorsal distance & -0.276 & $\mathbf{0 . 6 6 7}$ \\
Pre-ventral distance & -0.323 & $\mathbf{0 . 5 2 0}$ \\
C-peduncle length & -0.266 & $\mathbf{- 0 . 4 2 7}$ \\
C-base fin length & -0.219 & 0.302 \\
& & \\
Eigen value & 11.160 & 0.570 \\
Cumulative \% of total variance explained & 89.700 & 94.300 \\
\hline
\end{tabular}

LAT. Differentiation of populations in multidimensional space was determined with Wilk's $\lambda$ and $F$ and $P$ statistics. Statistical analyses (ANOVA, PCA, DFA) were made with usage of STATISTICA 8 software (Statsoft).

\section{Results}

The morphological measurements (Tabs. 2a and 2b) subjected to TRA (Tabs. $3 \mathrm{a}$ and $3 \mathrm{~b}$ ) revealed that a majority of characters were best described by simple linear regression, which means isometric growth. In the populations from Belgium (BWP) and England (E6T, ECS), at least six characters were best described by split linear regression, which indicates two intervals of isometric growth interrupted by a short interval of allometric growth. In BWP specimens, four characters (head length, postorbital distance, head depth and body depth) were in the same interval, with the breakpoints from 52.02 to $64.89 \mathrm{~mm}$ SL. In E6T specimens, five characters (pre-orbital distance, post-orbital distance, V-A, D-fin length and D-fin1 depth) were in the same interval, with the breakpoints from 116.50 to $118.24 \mathrm{~mm}$ SL. In ECS specimens, two intervals of breakpoints were clearly distinguishable - one from 30.59 to $51.32 \mathrm{~mm}$ SL for four characters (pre-orbital distance, pre-anal distance, $\mathrm{V}-\mathrm{A}$ and body depth), and the second interval from 74.75 to $93.64 \mathrm{~mm} \mathrm{SL}$ for five characters (head length, post-orbital distance, P-V, Cpeduncle length and A-fin length).

Correlation analysis identified characters, such as fin lengths (D, A, P, V), eye diameter and body depth which correlated significantly with SL (Tab. 4). Characters describing body shape and the caudal peduncle (pre-orbital distance, maxilla length, pre-dorsal distance, pre-ventral distance, Cpeduncle length and C-base fin length) significantly correlated with latitude (Tab. 4). Two characters (head length and P-base length) did not correlate with either SL or LAT, and none correlated with LONG.

Reliability of the dataset described by Cronbach $\alpha$ was 0.711. In PCA, $77 \%$ of total accumulated variance was 
Table 6. Comparison of particular morphological characters in Portuguese populations based on their local conditions.

\begin{tabular}{|c|c|c|c|c|}
\hline \multirow[t]{2}{*}{ Character } & \multicolumn{2}{|c|}{ Littoral/Pelagic } & \multicolumn{2}{|c|}{ Lacustrine/Riverine } \\
\hline & $P$ & $F$ & $P$ & $F$ \\
\hline Head length & 0.0000 & 29.120 & 0.0009 & 15.478 \\
\hline Pre-orbital distance & 0.4047 & 0.695 & 0.0002 & 13.768 \\
\hline Eye diameter & 0.0000 & 79.813 & 0.0334 & 4.538 \\
\hline Maxilla length & 0.0000 & 29.080 & 0.0004 & 12.750 \\
\hline Pre-dorsal distance & 0.0998 & 2.714 & 0.0100 & 6.667 \\
\hline Pre-ventral distance & 0.0007 & 15.863 & 0.0006 & 11.846 \\
\hline Body depth & 0.0000 & 41.217 & 0.6360 & 0.226 \\
\hline C-peduncle length & 0.0000 & 62.869 & 0.4000 & 0.709 \\
\hline C-base fin length & 0.0018 & 9.797 & 0.9511 & 0.004 \\
\hline D-fin length & 0.0000 & 23.621 & 0.6701 & 0.182 \\
\hline A-fin length & 0.0019 & 9.664 & 0.0037 & 8.450 \\
\hline P-fin length & 0.1539 & 2.036 & 0.6237 & 0.241 \\
\hline P-base length & 0.0001 & 20.687 & 0.3235 & 0.976 \\
\hline V-fin length & 0.0003 & 13.310 & 0.5943 & 0.284 \\
\hline
\end{tabular}

accounted by five factors, with $53 \%$ represented in first two components. The first component described the variability in characters with regard to SL (Fig. 2). The second component described morphological variability associated with latitude (characters with this direction are connected mainly with latitude; Fig. 2).

Results from correlation analysis to evaluate changes individually, as well as results from PCA analysis to evaluate total morphological variability, demonstrated that amongpopulation variations based on geographical area of occurrence were mainly in pre-orbital distance, maxilla length, pre-dorsal distance, pre-ventral distance, C-peduncle length and C-base fin length. Only these characters were later used in DFA for population discrimination. All characters had significant effect on distribution. In this case, it indicates that on average only $68.5 \%$ of specimens were correctly classified to proper population despite the first two canonical axes (accounted for $94 \%$ of the total variation). The overall value was a result of high similarity in proper correctly classified specimens of some populations (only $7.6 \%$ in EUC, $21.1 \%$ in FGL, $28.7 \%$ in ELC and $33.1 \%$ in BWP). Whereas, the specimens from Portugal were completely separated based on the characters mentioned above (Tab. 5). Their extreme separation was along the $x$-axis, though only one mensural character was significantly correlated to it. Thus, the populations from Portugal were characterized mainly by longer pre-orbital distance in comparison with other northern populations.

The variations within Portuguese populations can be linked to a habitat type (littoral vs. pelagic, as well as river $v s$. lake) at the five locations (Tab. 6). The significant difference was confirmed in all measured characters among specimens altogether from different habitat types and high variability was found also between particular types of conditions (ANOVA, Tab. 6). The littoral vs. pelagic habitat distinction had a stronger effect, with $75.5 \%$ of specimens correctly classified to their proper group (based on DFA), i.e. if any individual is selected without information about its relation- ship to the appropriate population, the probability of correct habitat categorisation of riverine vs. lacustrine would be low (slightly above random distribution) based on its morphological parameters. Only $62.5 \%$ of specimens were correctly classified as to their proper habitat in comparison to lacustrine vs. riverine populations. Also, DFA analysis correctly classified altogether (the combination of littoral vs. pelagic and lacustrine $v s$. riverine) only $49 \%$ into the proper population. Despite the within-population variations with regard to habitat, these variations were not sufficiently great to warrant the distinction of habitat types in subsequent analysis.

The overall morphometric variability in individual characters between European populations of L. gibbosus was great (ANOVA, Tukey's HSD post-hoc test, Tab. 7). However, the definitive adult phenotypes were achieved in the same manner in majority of populations. Across the European populations, another six mensural characters correlated significantly to SL development with five of them having biologically significant relationships (Tab. 8). In this case, the $62.2 \%$ of specimens were correctly classified to their proper population with $93.1 \%$ in PT and $75.3 \%$ in SCN and $0 \%$ in ELC and EBS, respectively $4.4 \%$ in EUC. Specimens from Portugal (all specimens combined) were characterized with shorter body depth and longer P-fin length. Specimens from Slovakia, besides these same two characters, were characterized by larger eye diameter and shorter dorsal and ventral fin lengths.

\section{Discussion}

Studies devoted to the understanding of invasion dynamics often look for differences among the successful and the unsuccessful invaders (Miller and Alcorn, 1945; Peterson and Fausch, 2003), and a high degree of phenotypic plasticity in life-history traits and external morphology is often observed in the invading species (Balážová-Lavrinčíková and Kováč, 2007; Tomeček et al., 2007; Feiner et al., 2012; Záhorská et al., 2013). Owing to this plasticity, a species is able to adapt 
Table 7. Comparison of differences between individual 14 traits in 13 populations observed. Tukey's $P$ describes the number $(n)$ of positively significant differences between individual population in given trait (maximal number is 78). The number of positive inter-population differences gives the number of significant differences in individual population from remaining 12 in given character (see Tab. 1 for study site codes).

\begin{tabular}{|c|c|c|c|c|c|c|c|c|c|c|c|c|c|c|c|c|}
\hline Character & $P$ & $F$ & Tukey's $P(n)$ & NSP & NMP & ELC & EUC & ECS & E6T & EBS & BWP & BSS & $\mathrm{SCN}$ & FBM & FGL & PT \\
\hline \multicolumn{17}{|c|}{ Number of positive interpopulation differences } \\
\hline Head length & 0 & 37.20 & 48 & 6 & 7 & 4 & 6 & 9 & 7 & 7 & 6 & 8 & 9 & 12 & 8 & 7 \\
\hline Pre-orbital distance & 0 & 772.00 & 51 & 7 & 6 & 6 & 6 & 6 & 5 & 10 & 9 & 5 & 10 & 10 & 10 & 12 \\
\hline Eye diameter & 0 & 74.93 & 56 & 12 & 10 & 8 & 9 & 8 & 12 & 5 & 8 & 7 & 10 & 9 & 7 & 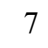 \\
\hline Maxilla length & 0 & 293.87 & 62 & 8 & 8 & 9 & 8 & 8 & 9 & 9 & 10 & 12 & 10 & 12 & 9 & 12 \\
\hline Pre-dorsal distance & 0 & 190.42 & 59 & 8 & 7 & 8 & 11 & 11 & 12 & 6 & 8 & 7 & 8 & 10 & 11 & 11 \\
\hline Pre-ventral distance & 0 & 245.07 & 55 & 6 & 7 & 8 & 10 & 10 & 9 & 6 & 8 & 7 & 8 & 11 & 8 & 12 \\
\hline Body depth & 0 & 96.58 & 61 & 10 & 10 & 8 & 8 & 8 & 10 & 9 & 10 & 8 & 8 & 10 & 12 & 11 \\
\hline C-peduncle length & 0 & 161.64 & 54 & 10 & 8 & 6 & 6 & 6 & 10 & 7 & 7 & 8 & 9 & 11 & 9 & 11 \\
\hline C-base fin length & 0 & 140.57 & 56 & 9 & 9 & 7 & 8 & 6 & 7 & 9 & 8 & 9 & 10 & 9 & 9 & 12 \\
\hline D-fin length & 0 & 77.97 & 56 & 11 & 7 & 6 & 6 & 6 & 11 & 6 & 7 & 12 & 9 & 11 & 11 & 9 \\
\hline A-fin length & 0 & 50.50 & 58 & 9 & 11 & 9 & 8 & 8 & 9 & 6 & 9 & 8 & 8 & 9 & 12 & 10 \\
\hline P-fin length & 0 & 94.54 & 57 & 7 & 7 & 8 & 8 & 6 & 11 & 6 & 10 & 12 & 11 & 7 & 9 & 12 \\
\hline P-base length & 0 & 73.55 & 58 & 10 & 7 & 7 & 8 & 8 & 9 & 9 & 8 & 10 & 11 & 10 & 10 & 9 \\
\hline V-fin length & 0 & 66.60 & 52 & 6 & 7 & 7 & 5 & 8 & 12 & 6 & 8 & 11 & 9 & 7 & 8 & 10 \\
\hline
\end{tabular}

Table 8. Canonical loadings (i.e. correlations) for all populations between traits and each canonical axis in the overall discriminant functional analysis (DFA) concerning the effect of standard length. Traits with correlations that are greater than or equal to an absolute value of 0.4 are considered to have biologically significant relationships (in boldface; McGarigal et al., 2000).

\begin{tabular}{lrr}
\hline \multicolumn{3}{c}{ Discriminant function analysis } \\
\hline Morphometric characters & Axis 1 & \multicolumn{1}{c}{ Axis 2 } \\
\hline Eye diameter & -0.1701 & $\mathbf{- 0 . 6 1 3 4}$ \\
Body depth & $\mathbf{0 . 5 5 2 6}$ & 0.1873 \\
D-fin length & 0.2748 & $\mathbf{0 . 4 2 4 9}$ \\
A-fin length & 0.1703 & 0.1854 \\
P-fin length & $\mathbf{- 0 . 6 0 0 2}$ & -0.0735 \\
V-fin length & -0.1688 & $\mathbf{0 . 5 1 2 3}$ \\
& & \\
Eigen value & 0.8048 & 0.6675 \\
Cumulative \% of total variance explained & 0.3314 & 0.6063 \\
\hline
\end{tabular}

to local conditions and establish a population in these novel environments. Indeed, in native populations of $L$. gibbosus as much as $53 \%$ of morphological plasticity was found to be caused phenotypically (by environmental conditions) and only $14 \%$ genetically (Robinson et al., 2000). However, the selection process associated with adaptation to a novel environment can eventually lead to a reduction in plasticity. This was demonstrated in recent research that compared the progeny of indigenous L. gibbosus populations in Ontario, Canada, with the progeny of L. gibbosus stocks repatriated from the species' introduced range in Spain. Both sets of progeny were reared under identical conditions in Ontario, Canada. Progeny of the repatriated L. gibbosus were found to be morphologically less plastic than progeny of the indigenous
L. gibbosus in response to sustained water velocities, habitat type, locomotion, competition (Yavno and Fox, 2013, 2014; Yavno et al., 2013, 2014).

As such, the effect of environment on the morphology of L. gibbosus is indisputable, with geographical location playing an important role in how populations adapt to local conditions. Morphology can vary within (pelagic vs. littoral) and between different types of habitat (riverine $v s$. lacustrine). For example, stream-dwelling L. gibbosus in the species introduced range (Iberia) were found to have longer pelvic and pectoral fins than those inhabiting lakes (Naspleda et al., 2012), whereas in the native range, stream-dwelling $L$. gibbosus populations had more robust caudal peduncles and more anterior fin positions than did their lake con-specifics (Brinsmead and Fox, 2002). These four characters are functionally significant for locomotion and the conditions in streams are different than in lakes (e.g. water velocity, macrophyte abundance). Also, L. gibbosus from the limnetic zone are characteristically more shallow-bodied, with smaller heads, shorter pectoral fins, longer and deeper caudal peduncles, and more anterior placement of the pectoral and pelvic fins than L. gibbosus occupying the littoral zone of the same lake (Robinson et al., 2000; Gillespie and Fox, 2003).

These earlier results are consistent with our results for introduced European populations of L. gibbosus. Indeed, several differences in traits were identified in Portuguese populations within individuals from littoral and pelagic zones; as well as between individuals from rivers and lakes (Tab. 6). These results emphasize the phenotypic plasticity of the species in response to changing local conditions, not only in terms of morphology (this study) but other life-history traits (Fox and Copp, 2014). However, when examining the populations from at a larger scale, there do not appear to be broad geographical patterns in morphology. Whereas, there do appear to be broader geographical patterns in the ontogenetic trajectories that L. gibbosus populations follow in achieving 
shorter eye diameter
longer dorsal fin length
longer ventral fin length

longer eye diameter shorter dorsal fin length shorter ventral fin length

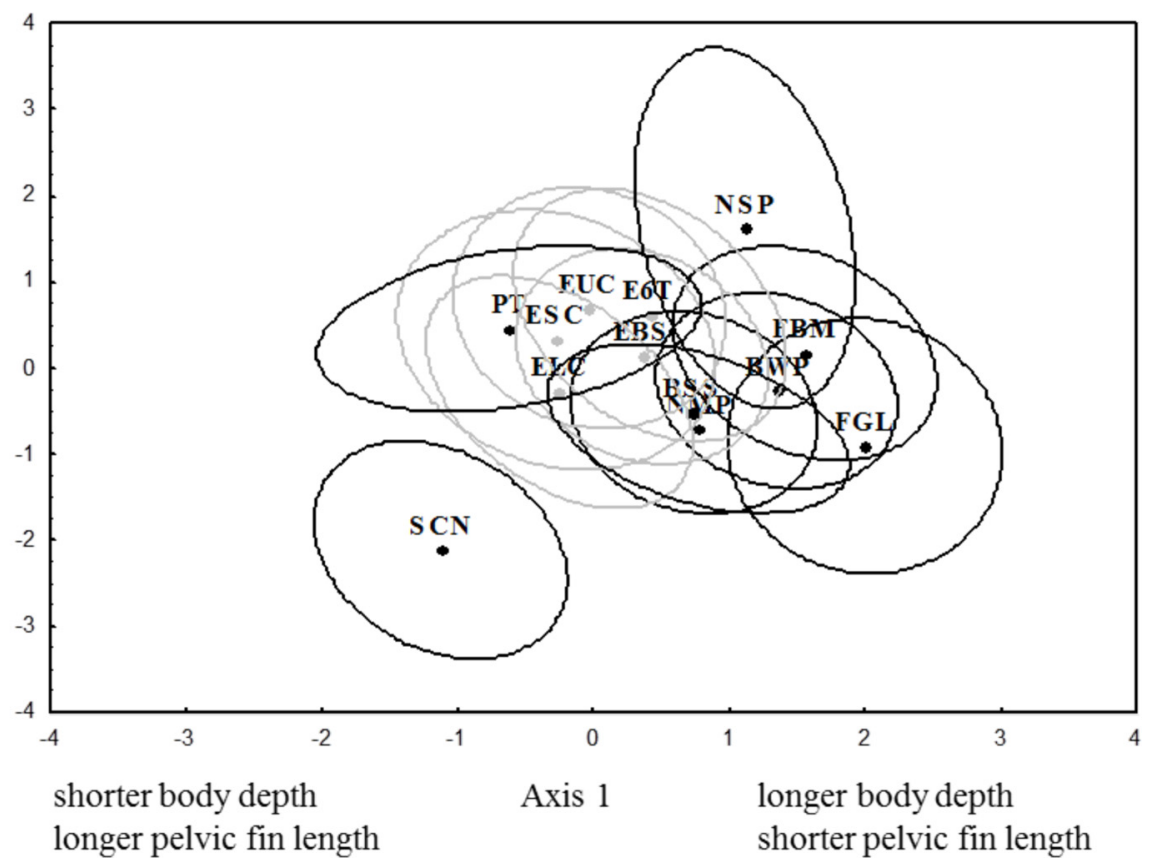

Fig. 3. Discriminant functional analysis scatter plot (DFA) with means of canonical variables and $50 \%$ ellipsoids about the centroid of each population of pumpkinseed from 12 different sites and latitudes, with discrimination based on morphological variability of 5 characters significantly correlated with SL. Abbreviations for populations are available in Table 1.

their definitive phenotype. The two different, distinguishable developmental trajectories (Kováč, 2011) reflect differences in the allocation of sources at different stage of invasion process. This resembles the differences in growth and life-history traits observed in another invasive species, round goby Neogobius melanostomus, at its invasion fronts in both Europe and North America (e.g. Brandner et al., 2013; Masson et al., 2016). In the majority of L. gibbosus populations, isometric growth predominated over non-isometric growth (i.e. allometric and abrupt isometric) in most morphometric characters (Tabs. 3a and $3 \mathrm{~b}$ ). That means that the external shape of these individuals developed early, when they were of small size $(<60 \mathrm{~mm} \mathrm{SL}$; Tomeček et al., 2005). The second type of development was apparent in specimens from Belgium (BWP) and England (ECS), where non-isometric growth predominated in most characters (Tabs. 3a and 3b). Non-isometric growth is also evident for several morphometric characters for the population from England (E6T). The high frequency of non-isometric growth with characters in these populations represents more extended, slower development. Furthermore, the presence of characters that grew isometrically until a certain size was reached, and then changed abruptly to grow isometrically again, raises the question of whether the shifts in proportions of these characters indicate one or more life-history thresholds. Such a question becomes appropriate if the majority of break points (in otherwise isometric growth) appear within a narrow interval of SL (Kováč et al., 1999).

The coincidence of breakpoints may indicate developmental thresholds and/or transitions, although only if these are associated with other ecological, physiological and/or behavioural changes (Tomeček et al., 2005). In Webbekomsbroek Pond, Belgium (a population with slower development), the break points were observed in narrow interval of SL (52.02$64.89 \mathrm{~mm}$ ). All traits in this interval were connected with the changes of head and body, which appears to define the threshold between the juvenile and adult periods of development. In the Cottesmore School population (England), there were two narrow intervals of SL. One of these was at small size (30.59-51.32 mm SL) and involved traits connected with changes to the head and body; this appears to represent a lifehistory interval during which some remodelling of external body shape occurs. The second interval was at larger size (74.75-93.64 mm SL) and involved traits associated with changes to the head and fins. This contrasted the angling pond (E6T) which is only $25 \mathrm{~km}$ away from Cottesmore School, where the growth of most traits was linear, but changes of the external shape (head, fins, V-A distance) of these fish appeared at a larger SL $(116.50-118.24 \mathrm{~mm})$ and were probably associated with reproduction development.

The effect of SL was apparent in five characters that clearly distinguished the Slovak population (SCN; Fig. 3, which was characterized by a unique, shallower body shape, with longer eye diameter, short D- and V-fin lengths, and a longer P-fin length (Tab. 8). A similar effect of SL was observed in a French population (FGL), which was characterized by short P-fin length and wider body (Fig. 3), but with slight difference in sizes of D- and V-fin lengths and in eye diameter. Both are from the small lakes, and thus the habitat type (pelagic vs. littoral) should not play a major role. The possible explanation of this difference would be in character of the water bodies.

All populations analysed overlap morphologically without formation of any other significant model except for Slovakia, which was distinctly separated. However, the ellipsoid of Portuguese population overlapped on one side with others (especially the English populations), but on the other side (based on the DFA analyses) as many as $93 \%$ of individuals were correctly classified to their proper population. This suggests the existence of another unique morphological model. Despite the 


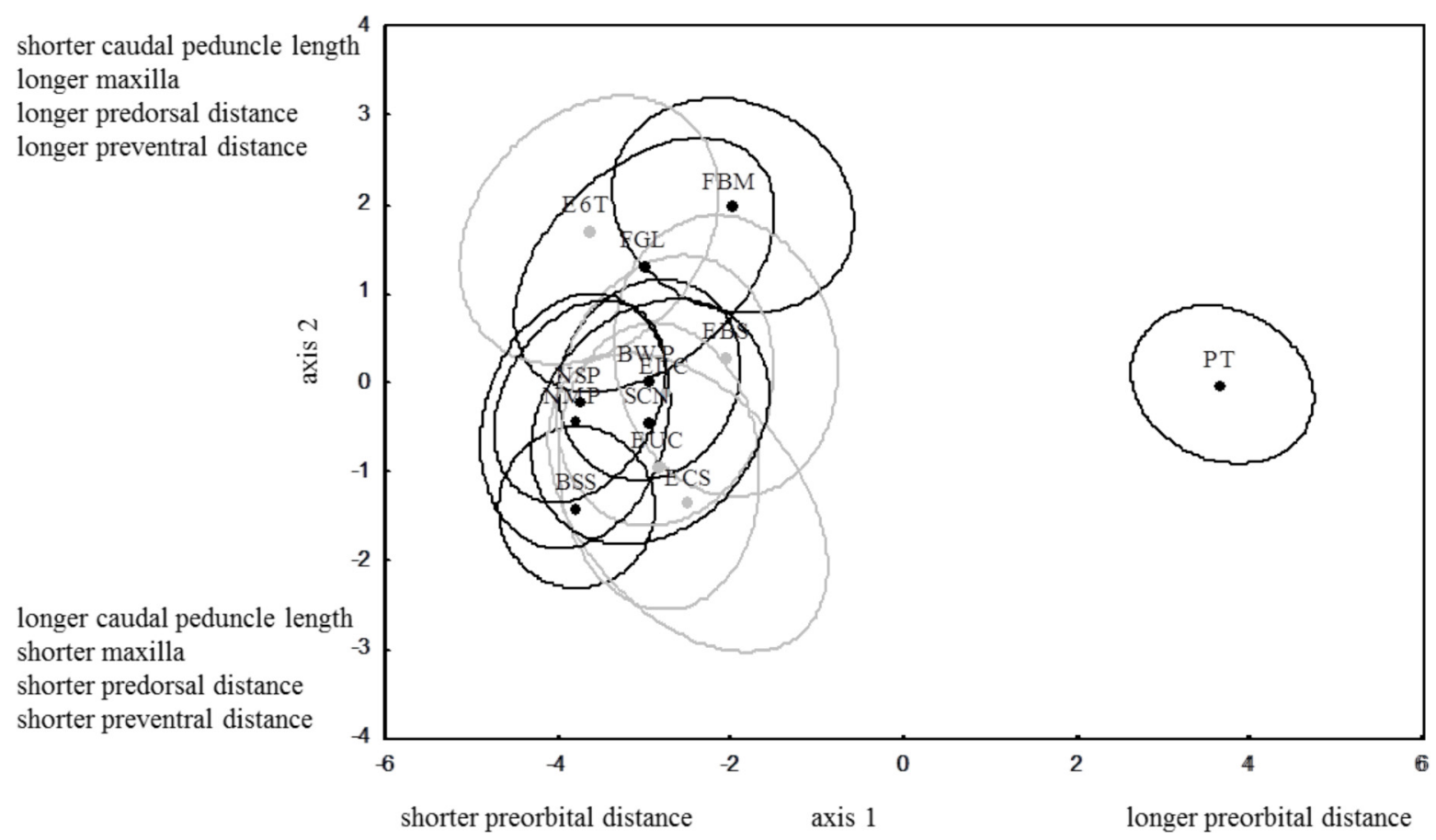

Fig. 4. Discriminant functional analysis scatter plot (DFA) with means of canonical variables and $50 \%$ ellipsoids about the centroid of each population of pumpkinseed from 12 different sites and latitudes, with discrimination based on morphological variability of 5 characters significantly correlated to latitude. Abbreviations for populations are available in Table 1.

great variability of Portuguese individuals (almost 900 individuals), most of them correspond with the morphological model localized around the determined population centroid, which is characterized by shorter body depth and longer P-fin length. At the same time, it differs from the Slovakian population, which has shorter eye diameter and longer D- and V-fin lengths.

Of the characters hypothesised by Copp et al. (2002) to vary with latitude (i.e. C-peduncle length, D-fin length and depth), only one character (C-peduncle length) demonstrated a significant relationship with latitude (Figs. 3 and 4). On the other hand, we identified four other characters (maxilla length, pre-dorsal, pre-ventral and pre-orbital distances; Tab. 4) that varied with latitude but not with LONG ( $c f$. Section 3). Lifehistory traits are known to vary with latitude (Copp and Fox, 2007), which as such has been used as surrogate for water temperature (Cucherousset et al., 2009). In the present context, this emphasizes the potential influence of geographical location on L. gibbosus biology. The strongest effect of latitude was visible on Portuguese populations (Fig. 4), which distinguished themselves from the other 16 populations in terms of snout size. This can be connected with the different size of the eye (even if this trait did not differ significantly). The remainder of the populations formed one cluster and differed significantly in remaining four characters (without pre-orbital distance).

This is the first known morphological study in which several non-native populations of $L$. gibbosus have been compared across a broad geographical area. The hypothesis that populations from the same region will be morphologically similar and will be morphologically distinct from the populations in other regions is corroborated, morphological variability due to latitude was identified. The geographical distinction between populations is apparent at a finer scale in the two different ontogenetic trajectories that pumpkinseed followed to achieve their definitive phenotype (Kováč, 2011). As such, the present study has demonstrated the considerable phenotypic plasticity of L. gibbosus in terms of morphological adaptations, such as observed in growth and life-history traits of both native and introduced populations (Fox and Copp, 2014).

Acknowledgements. Elaborated within the framework of an international network initiated with a NATO Science Programme "Collaborative Linkage Grant" (awarded to G. H. Copp and V. Kováč), this study was funded by the Slovak Scientific Grant Agency (Project No. 1/0392/12; awarded to E. Záhorská) and UK Department for Environment, Food and Rural Affairs. We thank the following persons for assisting in the collection and processing of pumpkinseed in Belgium (Y. Maes, I. Lambeens, M. De Wit, S. Buekenhout), England (M. G. Fox, M.J. Godard, M. Ives, R. Bush, D. Langley), France (J. Cucherousset, J.-M. Paillisson, A. Carpentier, J.-P. Damien), and Portugal (A. Albuquerque, R. Rivaes, C. Abreu, J. Santos). We thank V. Kováč and M.G. Fox for their expert advice.

\section{References}

Alpert P. 2006. The advantages and disadvantages of being introduced. Biol Invasions 8: 1523-1534.

Balážová-Lavrinčíková M, Kováč V. 2007. Epigenetical context in the life-history of round goby Neogobius melanostomus from Slovak stretch of the Danube. In: Gherardi F, ed. Freshwater bioinvaders: profiles, distribution, and threats. Dordrecht: Springer-Verlag, pp. 275-287.

Bhagat Y, Fox MG, Ferreira MT. 2006. Morphological differentiation in introduced pumpkinseed Lepomis gibbosus (L.) occupying 
different habitat zones in Portuguese reservoirs. J Fish Biol 69: 79-94.

Bhagat Y, Wilson CC, Fox MG, Ferreira MT. 2011a. Genetic relationships among pumpkinseed (Lepomis gibbosus) ecomorphs in freshwater reservoirs of Portugal. Ecol Freshw Fish 20: 287-298.

Bhagat Y, Wilson CC, Fox MG, Ferreira MT. 2011b. Trophic polymorphism in introduced pumpkinseed (Lepomis gibbosus) inhabiting Iberian reservoirs. Environ Biol Fish 91: 203-217.

Bobori DC, Tsikliras AC, Economidis NI. 2006. Some morphological and biological characteristics of fishes from Tavropos Reservoir (western Greece). Folia Zool 55: 199-210.

Brandner J, Cerwenka AF, Schliewen UK, Geist J. 2013. Bigger is better: characteristics of round gobies forming an invasion front in the Danube River. PLOS ONE 8: e73036.

Brinsmead J, Fox MG. 2002. Morphological variation between lakeand stream-dwelling rock bass and pumpkinseed populations. J Fish Biol 61: 1619-1638.

Copp GH, Fox MG. 2007. Growth and life history traits of introduced pumpkinseed (Lepomis gibbosus) in Europe, and the relevance to its potential invasiveness. In: Gherardi F, ed. Freshwater bioinvaders: profiles, distribution, and threats. Dordrecht: Springer-Verlag, pp. 289-306.

Copp GH, Fox MG, Kováč V. 2002. Growth, morphology and life history traits of a cool-water European population of pumpkinseed Lepomis gibbosus. Arch Hydrobiol 155: 585-614.

Cucherousset J, Paillisson JM, Carpentier A, Eybert MC, Olden JD. 2006. Use of an artificial wetland by the invasive catfish Ameirus melas. Ecol Freshw Fish 15: 589-596.

Cucherousset J, Copp GH, Fox MG, et al. 2009. Life-history traits and potential invasiveness of introduced pumpkinseed Lepomis gibbosus populations in northwestern Europe. Biol Invasions 11: 2171-2180.

Feiner ZS, Aday DD, Rice JA. 2012. Phenotypic shifts in white perch life history strategy across stages of invasion. Biol Invasions 14: 2315-2329.

Fobert E, Zięba G, Vilizzi L, et al. 2013. Predicting non-native fish dispersal under conditions of climate change: case study in England of dispersal and establishment of pumpkinseed Lepomis gibbosus in a floodplain pond. Ecol Freshw Fish 22: 106-116.

Fox MG, Copp GH. 2014. Old world vs new world - life history alterations in a successful invader introduced across Europe. Oecologia 174: 435-446.

Fox MG, Villeneuve F, Copp GH. 2011. Seasonal reproductive allocation, local-scale variation and environmental influences on life history traits of introduced pumpkinseed (Lepomis gibbosus) in southern England. Fund Appl Limnol 178: 231-243.

García-Berthou E, Alcaraz C., Pou-Rovira Q., Zamora L., Coenders G., Feo C. 2005. Introduction pathways and establishment rates of invasive aquatic species in Europe. Can J Fish Aquat Sci 62: 453-463.

Gillespie GJ, Fox MG. 2003. Morphological and life history differentiation between littoral and pelagic forms of pumpkinseed (Lepomis gibbosus). J Fish Biol 62: 1099-1115.

Kováč V. 2011. Genes and development. In: Hutchins M, ed. Grzimek's animal life encyclopedia. Evolution. Farmington Hills, MI: Gale, pp. 141-150.

Kováč V, Copp GH, Francis MP. 1999. Morphometry of the stone loach, Barabatula barbatula: do morphometric characters reflect the species' life history thresholds? Environ Biol Fish 56: 105-115.

Künstler J. 1908. Ameiurus nebulosus et Eupomotis gibbosus. Bulletin de la Societé d'Acclimatation 238-244.

Lavrinčíková M, Kováč V, Katina S. 2005. Ontogenetic variability in external morphology of round goby Neogobius melanostomus from Middle Danube, Slovakia. J Appl Ichthyol 21: 328-334.
Masson L, Brownscombe JW, Fox MG. 2016. Fine scale spatiotemporal life history shifts in an invasive species at its expansion front. Biol Invasions 18: 775-792.

McGarigal K, Cushman SA, Stafford S. 2000. Multivariate statistics for wildlife and ecology research. New York: Springer-Verlag, $283 \mathrm{p}$.

Miller RR, Alcorn JR. 1945. The introduction of fishes of Nevada, with a history of their introduction. Trans Am Fish Soc 73: 173-193.

Naspleda J, Vila-Gispert A, Fox MG, Zamora L, Ruiz-Navarros A. 2012. Morphological variation between non-native lake- and stream-dwelling pumpkinseed Lepomis gibbosus in the Iberian Peninsula. J Fish Biol 81: 1915-1935.

Paillisson JM, Marion M. 2006. Can small water level fluctuations affect the biomass of Nymphaea alba in large lakes? Aquat Bot 84: 259-266.

Peterson DP, Fausch KD. 2003. Testing population-level mechanisms of invasion by a mobile vertebrate: a conceptual framework for salmonids in streams. Biol Invasions 5: 239-259.

Robinson BW, Wilson DS. 1996. Genetic variation and phenotypic plasticity in a trophically polymorphic population of pumpkinseed sunfish (Lepomis gobbosus). Evol Ecol 10: 631-652.

Robinson BW, Wilson DS, Margosian AS. 2000. A pluralistic analysis of character release in pumpkinseed sunfish (Lepomis gibbosus). Ecology 81: 2799-2812.

Sakai AK, Allendorf FW, Holt JS, et al. 2001. The population biology of invasive species. Ann Rev Ecol Syst 32: 305-332.

Sedlár J. 1957. A contribution to distribution and biometrics of pumpkinseed (Lepomis gibbosus Linne, 1758) and catfish (Ameiurus nebulosus Le Sueur, 1819) in southern Slovakia. Pol'nohospodárstvo 4: 1104-1109.

Šumer S, Kováč V, Povž M, Slatner M. 2005. External morphology of a Slovenian population of pumpkinseed Lepomis gibbosus (L.) from a habitat with extreme thermal conditions. J Appl Ichthyol 21: 306-311.

Tandon KK. 1976. Note on the systematics of the pumpkinseed, Lepomis gibbosus (Osteichthyes, Perciformes, Centrarchidae). Vèstník Československé Zoologické Spoločnosti 40: 307-311.

Tandon KK. 1977. Age and growth study of Lepomis gibbosus from Italy. Věstník Československé Zoologické Spoločnosti 41: 211-217.

Tomeček J, Kováč V, Katina S. 2005. Ontogenetic variability in external morphology of native (Canadian) and non-native (Slovak) populations of pumpkinseed (Lepomis gibbosus, Linnaeus 1758). $J$ Appl Ichthyol 21: 335-344.

Tomeček J, Kováč V, Katina S. 2007. Biological flexibility of pumpkinseed, a successful coloniser throughout Europe. In: Gherardi F, ed. Freshwater bioinvaders: profiles, distribution, and threats. Dordrecht: Springer-Verlag, pp. 307-336.

Van Thuyne G, Breine J. 2005. Visbestandopnames op de hengelvijver van het Webbekomsbroekte Webbekom. HoeilaartGroenendaal, Belgium: Instituut voor Bosbouw en Wildbeheer.

Villeneuve F, Copp GH, Fox MG, Stakènas S. 2005. Interpopulation variation in the growth and life history traits of the introduced sunfish, pumpkinseed Lepomis gibbosus, in Southern England. J Appl Ichthyol 21: 275-281.

Yavno S, Fox MG. 2013. Morphological change and phenotypic plasticity in native and non-native pumpkinseed sunfish in response to sustained water velocities. J Evol Biol 26: 2383-2395.

Yavno S, Fox MG. 2014. Morphological plasticity in native and nonnative pumpkinseed sunfish in response to habitat type. Evol Ecol Res 16: 373-395. 
Yavno S, Fox MG, Vila-Gispert A, Bhagat Y. 2013. Morphological differences between native and non-native pumpkinseed in traits associated with locomotion. Environ Biol Fish 96: 507-518.

Yavno S, Rooke AC, Fox MG. 2014. Morphological change and phenotypic plasticity in native and non-native pumpkinseed sunfish in response to competition. Naturwissenschaften 101: 479-492.
Záhorská E, Kováč V, Falka I, et al. 2009. Morphological variability of the Asiatic cyprinid, topmouth gudgeon Pseudorasbora parva, in its introduced European range. J Fish Biol 74: 167-185.

Záhorská E, Švolíková K, Kováč V. 2013. Do invasive populations of topmouth gudgeon (Pseudorasbora parva, Temminck and Schlegel) from disturbed and undisturbed habitats follow different lifehistories? Int Rev Hydrobiol 98: 61-70.

Cite this article as: Záhorská E, Balážová M, Bhagat Y, Copp GH. 2017. Does latitude drive the phenotypic plasticity of morphological traits in non-native pumpkinseed populations from Europe? Knowl. Manag. Aquat. Ecosyst., 418, 29. 